\title{
PENGARUH VARIASI BEBAN DALAM MENGOLAH AIR LIMBAH RUMAH PEMOTONGAN AYAM MENGGUNAKAN GAS-SBR
}

\author{
Indri Septiana \\ Jurusan Teknik Lingkungan, Fakultas Arsitektur Lanskap dan Teknologi Lingkungan, \\ Universitas Trisakti, Jakarta, Indonesia
}

Email korespondensi: indri08214033@std.trisakti.ac.id

\begin{abstract}
ABSTRAK
Meningkatnya usaha rumah pemotongan ayam (RPA) menjadi usaha kecil yang banyak diminati di karenakan tingginya jumlah konsumsi daging ayam dan telur karena harganya yang murah dan terjangkau masyarakat. Di karenakan hal tersebut, meningkatnya jumlah konsumsi daging ayam akan berdampak pada meningkatnya air limbah yang dihasilkan pada industri RPA. Agar limbah yang dihasilkan oleh RPA tidak mencemari lingkungan sekitar, maka dibutuhkan pengolahan limbah teknologi tepat guna yang mudah digunakan yaitu, Granular Aerobic Sludge Sequencing Batch Reactor (GAS-SBR) di karenakan limbah RPA memiliki kandungan organik yang tinggi. Sequencing Batch Reactor adalah pengolahan biologis dengan system pertumbuhan biologi tersuspensi. SBR merupakan variasi dari lumpur aktif, dimana terjadi tahapan yang terdapat pada lumpur aktif mulai dari fill, react, settle, decant hingga idle terjadi dalam satu tangki. Pada karya ilmiah ini digunakan variasi beban dalam fase fill yaitu sebesar 100\%, 75\%, dan 50\% air limbah RPA. Granular Aerobic Sludge (GAS) dapat di artikan sebagai agregat yang berasal dari mikroorganisme yang tidak berkoagulasi, secara signifikan mengendap lebih cepat apabila dibandingkan dengan flok lumpur aktif, dan mempunyai diameter dan metode pemanenan tertentu. Dengan terbentuknya granular aerob pada unit SBR ini, proses pengolahan biologis dan proses pengendapan dapat terjadi dalam satu unit atau satu tangki. Tidak membutuhkan unit pengendapan atau clarifier terpisah untuk proses pengendapan setelah proses pengolahan biologis.
\end{abstract}

Kata Kunci: Air limbah RPA, Granular Aerobic Sludge, Sequencing Batch Reaktor

\section{PENDAHULUAN}

Usaha rumah pemotongan ayam (RPA) di Indonesia telah menjadi sebuah kegiatan industri kecil yang perkembangannya memberikan kontribusi nyata dalam sektor ekonomi dari sektor hulu sampai ke sektor hilir. Hal ini dikarenakan produk unggas yang termasuk ayam, yakni daging ayam dan telur harganya relatif murah dan mudah di dapatkan sehingga dapat di jangkau oleh masyarakat luas (Singgih dan Kariana, 2008). Dengan meningkatnya jumlah konsumsi daging ayam akan berdampak pada meningkatnya air limbah yang dihasilkan industri Rumah Pemotongan Ayam (RPA) (Al Kholif, 2015). Air limbah pemotongan ayam dapat bertindak sebagai media pertumbuhan dan perkembangan mikroba karena mengandung protein, karbohidrat, lemak dan garam sehingga mudah sekali mengalami pembusukan. Agar limbah tidak mencemari lingkungan, di butuhkan teknologi pengendalian pencemaran yang tepat guna untuk mengolah limbah secara efisien yang dapat mengurangi beban organik dalam air limbah, yaitu salah satunya dengan menerapkan prinsip pembentukan granulasi aerobic sludge di dalam Sequencing Batch Reactor (SBR). Tujuan dari karya ilmiah ini adalah mengkaji upaya untuk mengolah air limbah rumah pemotongan ayam dengan memperhatikan hasil evaluasi pengolahan air limbah. 


\section{TINJAUAN PUSTAKA}

\section{Pengertian, Karakteristik, Dampak, dan Kandungan Air Limbah Pemotongan Ayam}

Rumah Pemotongan Ayam (RPA) adalah industri yang mengolah ayam hidup menjadi karkas siap olah untuk di konsumsi. RPA dapat dibedakan menjadi RPA skala kecil maupun RPA skala besar. RPA dapat menjadi salah satu penyebab pencemaran lingkungan.

Limbah pemotongan hewan (RPH) yang berupa feses, urin, isi rumen atau isi lambung, darah, daging atau lemak dan air cuciannya dapat bertindak sebagai media pertumbuhan dan perkembangan mikroba sehingga limbah tersebut mudah mengalami pembusukan (Suharto, 2010). Karakteristik air limbah RPA dapat digolongkan menjadi tiga bagian, yaitu (Kusnoputranto, 1985):

1. Karakteristik Fisik

Salah satunya adalah kekeruhan. Kekeruhan dapat terjadi karena adanya proses penguraian zat organik yang di lakukan oleh mikroorganisme.

2. Karakteristik Kimia

Kandungan kimia yang terdapat pada limbah dibedakan menjadi 2 jenis, yaitu yang mengandung campuran zat kimia anorganik dan zat kimia organik.

3. Karakteristik Biologis

Karakteristik biologi dipengaruhi oleh mikroorganisme yang terdapat pada air limbah. Mikroorganisme yang terdapat pada limbah antara lain yaitu, alga, fungi, baktri, protozoa dan mikroorganisme pathogen.

Air limbah sampai dengan saat ini sebagian besar masuk ke badan air penerima lewat drainase atau saluran air tanpa diolah terlebih dahulu (Iswanto, 2010). Menurut Moses Laksono (2010) tingginya kandungan nutrient pada air limbah jika di buang ke perairan akan mengancam ekosistem aquatic dan akan menimbulkan eutrofikasi karena limbah RPA mengandung COD, BOD, TSS, minyak dan lemak.

Menurut peraturan Menteri Negara Lingkungan Hidup nomor 5 tahun 2014 tentang Baku Mutu Air Limbah bagi Kegiatan Rumah Pemotongan Hewan dapat di lihat dibawah ini:

\begin{tabular}{cc}
\hline Parameter & Konsentrasi \\
\hline BOD & $100 \mathrm{mg} / \mathrm{L}$ \\
\hline COD & $200 \mathrm{mg} / \mathrm{L}$ \\
\hline TSS & $100 \mathrm{mg} / \mathrm{L}$ \\
\hline Minyak dan Lemak & $15 \mathrm{mg} / \mathrm{L}$ \\
\hline NH3-N & $25 \mathrm{mg} / \mathrm{L}$ \\
\hline $\mathrm{pH}$ & $6-9$
\end{tabular}

Tabel 1 Baku Mutu Air Limbah

Sumber: Menteri Negara Lingkungan Hidup

Dalam pengolahan air limbah rumah potong ayam dengan proses biofilter anaerob-aerob dapat menghasilkan kualitas yang cukup baik dan memenuhi syarat standar baku mutu air limbah industri. Proses ini memiliki keunggulan antara lain biaya operasi rendah dibandingkan dengan proses lumpur aktif (Satmoko Yudo, 2006). 


\section{GAS-SBR}

Untuk mengurangi pencemaran lingkungan di badan air akibat dari limbah RPA, teknologi SBR dapat digunakan untuk mengurai zat pencemar tersebut. SBR merupakan pengolahan air limbah berdasarkan sistem activated sludge dan dioperasikan dalam sebuah siklus fill-and-draw (Vives, 2005). SBR mempunyai lima tahapan proses yang dilakukan secara beruturan yaitu, pengisian, reaksi, pengendapan, pembuangan dan stabilisasi dan setelah tahap terakhir proses, di mulai dari awal lagi sehingga menjadi sebuah siklus dan terjadi pada satu tangki yang sama (Lita, 2011). Pada penelitian sebelumnya, pengolahan air limbah rumah sakit menggunakan SBR dengan variasi pembebanan air limbah berdasarkan nilai COD yaitu 50\%, 80\%, dan 100\% serta variasi waktu aerasi 6 jam dan 8 jam dapat menghasilkan rentang hasil efisiensi penyisihan zat organik (COD) sebesar 36\%-81\%, efisiensi penyisihan ammonia-nitrogen sebesar 45\%-97\% dan efisiensi fosfat sebesar 55\%-95\% (Erillia, 2017). Menurut Gerardi (2010) berikut merupakan tahapan Sequencing Batch Reactor:

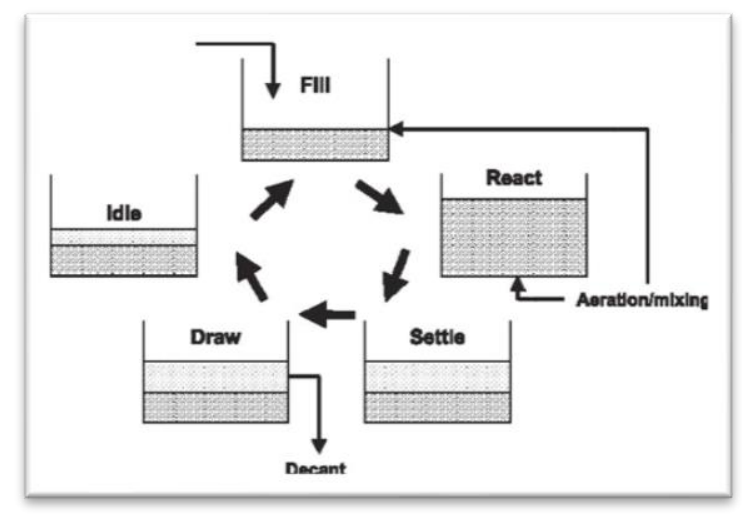

Gambar 1. Siklus dalam Sequencing Batch Reactor (SBR)

Salah satu media yang dapat digunakan dalam teknologi SBR adalah teknologi dengan menggunakan biomassa granular aerobic (Casto-Barros, 2013). Granular Aerobic Sludge (GAS) dapat didefinsikan sebagai agregat yang berasal dari mikroorganisme yang tidak berkoagulasi, dan secara signifikan mengendap lebih cepat bila dibandingkan dengan flok lumpur aktif (Ni, 2013). Keunggulan teknologi ini memiliki kemampuan pengendapan biomassa yang besar, karena densitas yang besar sehingga dapat memperkecil kebutuhan lahan untuk pengendapan (Beun, 2000). Reaktor SBR dan Sequencing Batch Airlift Reactor (SBAR) sering menjadi pilihan utama karena proses kontak dan pemisahan terjadi di dalam satu reaktor yang relative sederhana (Liu, 2006).

\section{PENUTUP}

Berdasarkan karya ilmiah di atas mengenai pengolahan air limbah rumah pemotongan ayam menggunakan GAS-SBR diharapkan di lakukan penelitian lebih lanjut karena tingginya kandungan organik yang terdapat di dalam air limbah rumah pemotongan ayam

\section{DAFTAR PUSTAKA}

Al Kholif. 2015. Pengaruh Penggunaan Media Dalam Menurunkan Kandungan Amonia Pada Limbah Cair Rumah Potong Ayam (RPA) Dengan Sistem Biofilter Anaerob. Jurnal Teknik Waktu

Beun. 2000. Aerobic granulation. Water Science \& Techonology 
Casto-Barros. C. M., Revised by Volcke, E. I. P. 2013. Guidline for granular sludge reactor design, SANITAS Sustainable and Integrated Urban Water System Management. Jurnal Sains dan Teknologi Lingkungan

Erillia Afifah Haque. 2017. Pengolahan Air Limbah Rumah Sakit dengan Sistem Lumpur Aktif Model SBR Skala Laboratorium. Thesis Institut Teknologi Sepuluh November Surabaya

Gerardi, Michael H. 2010. Troubleshooting the Sequencing Batch Reactor. A John Wiley\&Sons, Inc: New Jersey

DOI: $10.1002 / 9780470649633$

Iswanto, Bambang 2010. Teknologi Elektrokoagulasi Hasil Penelitian untuk Pengolahan Limbah Domestik. Indonesian Journal of Urban and Environmental Technology 5(4) : 113-136

DOI: http://dx.doi.org/10.25105/urbanenvirotech.v5i4.681

Kementerian Lingkungan Hidup Republik Indonesia 2014. Peraturan Menteri Lingkungan Hidup No. 5 Tahun 2014 Tentang Baku Mutu Air Limbah.

Kunoputranto, Haryoto. 1985. Kesehatan Lingkungan.FKM UI. Jakarta

Lita Darmayanti. 2011. Kinetika Penyisihan Nitrogen dalam Air Buangan Rumah Potong Hewan pada Sequencing Batch Reactor Aerob. Jurnal Teknobiologi

Liu, Y. 2006. Biosorption Properties of Aerobic Granules. Chapter in Waste Management Series 6:Biogranulation Technologies for Wastewater Treatment

DOI: https://doi.org/10.1016/S0713-2743(06)80113-3

Moses Laksono S. 2010. "Peningkatan Produktivitas dan Kinerja Lingkungan dengan Pendekatan Green Productivity Pada Rumah Pemotongan Ayam”. Jurnal Fakultas Teknologi Industri, Institut Teknologi Sepuluh Nopember Surabaya

Ni, B. J. 2013. Formation, characterization, and Mathematical Modelling of The Aerobic Granular Sludge. Springer Theses (Berlin)

DOI: http://dx.doi.org/10.1007/978-3-642-31281-6

Satmoko Yudo. 2006. Rancang Bangun Instalasi Pengolahan Air Limbah Rumah (RPH) Ayam dengan Proses Biofilter.

Singgih and Kariana. 2008. Peningkatan Produktivitas dan Kinerja Lingkungan Dengan Pendekatan Green Productivity Pada Rumah Pemotongan Ayam XX. Purifikasi: Jurnal Manajemen Lingkungan

DOI: $10.12962 / \mathrm{j} 25983806 . v 9.12 .149$

Vives. 2005. SBR Technology for Wastewater Treatment: Suitable Operational Conditions for a Nutrient Removal. Ph.D Thesis, Universitat de Girona. 